\title{
Extracellular proteins of Lactobacillus crispatus enhance activation of human plasminogen
}

Correspondence

Timo K. Korhonen

timo.korhonen@helsinki.fi

Received 4 August 2006

Revised 17 November 2006

Accepted 21 December 2006

\author{
Veera Hurmalainen ${ }^{1} \dagger$ Sanna Edelman, ${ }^{1} \dagger$ Jenni Antikainen, ${ }^{1}$ \\ Marc Baumann, ${ }^{2}$ Kaarina Lähteenmäki ${ }^{1}$ and Timo K. Korhonen ${ }^{1}$ \\ ${ }^{1}$ General Microbiology, Faculty of Biosciences, PO Box 56, FIN00014 University of Helsinki, \\ Finland \\ ${ }^{2}$ Protein Chemistry Unit, Institute of Biomedicine/Anatomy, PO Box 63, FIN00014 University \\ of Helsinki, Finland
}

\begin{abstract}
The abundant proteolytic plasminogen (Plg)/plasmin system is important in several physiological functions in mammals and also engaged by a number of pathogenic microbial species to increase tissue invasiveness or to obtain nutrients. This paper reports that a commensal bacterium, Lactobacillus crispatus, interacts with the Plg system. Strain ST1 of L. crispatus enhanced activation of human Plg by the tissue-type Plg activator (tPA), whereas enhancement of the urokinase-mediated Plg activation was lower. ST1 cells bound Plg, plasmin and PA only poorly, and the Plg-binding and activation-enhancing capacities were associated with extracellular material released from the bacteria into buffer. The extracellular proteome of L. crispatus ST1 contained enolase and glyceraldehyde-3-phosphate dehydrogenase (GAPDH) as major components. The enolase and the GAPDH genes of ST1 were cloned, sequenced and expressed in recombinant Escherichia coli as $\mathrm{His}_{6}$-fusion proteins, which bound Plg and enhanced its activation by tPA. Variable levels of secretion of enolase and GAPDH proteins as well as of the Plg activation cofactor function were detected in strains representing major taxonomic groups of the genus Lactobacillus. So far, interference with the Plg system has been addressed with pathogenic microbes. The results reported here demonstrate a novel interaction between a member of the microbiota and a major proteolytic system in humans.
\end{abstract}

\section{INTRODUCTION}

The plasminogen (Plg)/plasmin system is important in a wealth of physiological and pathological processes in mammals, and is also utilized by several microbial pathogens for migration within the host and to fulfil nutritional demands (reviewed by Castellino \& Ploplis, 2005; Lähteenmäki et al., 2001, 2005; Myöhänen \& Vaheri, 2004; Plow et al., 1995). Plg circulates at a high concentration, around $180-200 \mu \mathrm{g} \mathrm{ml}^{-1}$, in human plasma, and is also present in milk and other secretions (Myöhänen \& Vaheri, 2004; Wang et al., 2006). The liver is the primary tissue that synthesizes the proenzyme Plg. However, other identified tissue sources for Plg synthesis are numerous and include the intestine (Zhang et al., 2002). Plg activators

†These authors contributed equally to this work.

Abbreviations: $\alpha_{2} \mathrm{AP}, \alpha_{2}$-antiplasmin; EACA, $\varepsilon$-aminocaproic acid; GAPDH, glyceraldehyde-3-phosphate dehydrogenase; IEM, immunoelectron microscopy; PA, Plg activator; Plg, plasminogen; tPA, tissue-type Plg activator; uPA, urokinase.

The GenBank/EMBL/DDBJ accession numbers for the nucleotide sequences of $L$. crispatus ST1 gap and eno determined in this paper are AJ849470 and AJ849471.
(PAs) convert Plg into plasmin, which is a powerful serine protease whose major biological function is to dissolve fibrin clots. Plasmin is also involved in remodelling of vascular tissue, enhancement of cellular migration and damage of tissue barriers, initiation of autoimmune diseases, as well as in processes affecting pathogen susceptibility and inflammation, wound healing and neurologically related processes (Myöhänen \& Vaheri, 2004; Plow et al., 1995). In accordance with the central role of localized plasmin activity in the metastasis of tumour cells through basement membranes into secondary tissue sites, the research on microbe-Plg interactions has exclusively been done in connection with invasive bacterial infections. Indeed, the Plg system has been found to be critical for tissue and organ invasion by several severe pathogens (Coleman \& Benach, 1999; Lähteenmäki et al., 2001, 2005).

The Plg/plasmin system is tightly controlled under normal physiological conditions (Longstaff \& Thelwell, 2005; Myöhänen \& Vaheri, 2004). Mammals have two PAs, tissue-type Plg activator (tPA) and urokinase (uPA), which cleave Plg at a single site, thus forming the two-chain plasmin molecule joined via two disulfide bonds. Plg is hardly susceptible to activation without conformational or 
proteolytic modification. Plg is immobilized onto lysinecontaining Plg/plasmin receptors on bacterial and mammalian cell surfaces and onto lysine-containing cofactors such as fibrin, components of the extracellular matrix, denatured mammalian proteins and small molecule ligands (Castellino \& Ploplis, 2005; Longstaff \& Thelwell, 2005; Lähteenmäki et al., 2001). Immobilization is mediated by five so-called kringle domains of Plg and alters the conformation of Plg so that it becomes more susceptible to activation, in particular by tPA (Mangel $e$ t al., 1990). The serine protease domain is responsible for the proteolytic activity of plasmin (Longstaff \& Thelwell, 2005). The primary circulating inhibitor of plasmin is the antiprotease $\alpha_{2}$-antiplasmin $\left(\alpha_{2} \mathrm{AP}\right)$, which binds to the kringle domains and effectively inactivates soluble plasmin. When $\mathrm{Plg} /$ plasmin is bound to the cell surface or fibrin, its lysinebinding sites are occupied and $\alpha_{2} \mathrm{AP}$ acts more slowly. Microbial pathogens that utilize the Plg system for migration in the host overcome the control by cleaving $\alpha_{2} \mathrm{AP}$ or by immobilizing Plg on bacterial surface receptors (Lähteenmäki et al., 2005). Bacteria can also produce PAs; this has been detected in Yersinia pestis and Salmonella enterica, which express surface-bound proteolytic activators, as well as in staphylococci and streptococci, which produce secreted non-proteolytic activators called staphylokinase and streptokinase (Coleman \& Benach, 1999; Lähteenmäki et al., 2001, 2005).

The identified bacterial Plg receptors are multifunctional surface proteins (Lähteenmäki et al., 2001) and include cellwall-associated proteins previously assigned to metabolic functions only. The glycolytic enzymes enolase and glyceraldehyde-3-phosphate dehydrogenase (GAPDH) are cytoplasmic proteins that are also expressed on the surface of several, mainly Gram-positive, bacterial pathogens, as well as on fungal cells, parasites and mammalian cells. Surfaceassociated forms of bacterial enolase and GAPDH immobilize Plg and in this way enhance its activation; they also exhibit adhesive functions that may have a role in bacteriahost interactions (Bergmann et al., 2001, 2003; Broeseker et al., 1988; Chhatwal, 2002; Coleman \& Benach, 1999; Lähteenmäki et al., 2001, 2005).

Species of the genus Lactobacillus are important members of the indigenous microbiota in the human intestine and genitourinary tract, which has aroused interest in their role as health-promoting, probiotic organisms (Mercenier et al., 2003). The presence of a biologically functional extracellular proteome in commensal lactobacilli has been indicated by recent findings showing that proteins in the conditioned, cell-free culture medium of Lactobacillus rhamnosus GG modulate signal transduction pathways and prevent cytokine-induced apoptosis and heat-shock protein expression in human and mouse intestinal cell lines (Tao et al., 2006) as well as decrease chemokine production in mouse macrophages (Peña \& Versalovic, 2003). Recently, GroEL, a cytoplasmic heat-shock protein, was also shown to be present on the surface and in the cell-free culture medium of
Lactobacillus johnsonii NCC 533 and found to have adhesive and immunomodulatory effects in human and murine cells (Bergonzelli et al., 2006). A recent in silico analysis of the genome of Lactobacillus plantarum predicted the existence of 57 proteins that are secreted into the medium or remain associated with the cell wall by unknown anchoring mechanisms (Boekhorst et al., 2006). Here, we describe the presence of extracellular forms of the glycolytic enzymes enolase and GAPDH in Lactobacillus crispatus as well as their functions as Plg activation cofactors. These results further indicate the importance of extracellular proteins in the cross-talk between lactobacilli and their hosts, as well as demonstrating a novel variant in bacteria-Plg interaction mechanisms.

\section{METHODS}

Bacteria. Strain ST1 of L. crispatus was isolated from chicken faeces and shows adhesiveness to chicken and human cells (Edelman, 2005; Edelman et al., 2002). Lactobacillus acidophilus E507 (Miettinen et al., 1996), Lactobacillus amylovorus JCM 5807 (Mitsuoka, 1969), Lactobacillus gallinarum T-50, Lactobacillus gasseri JCM 1130/ATCC 19992 and Lactobacillus johnsonii F133 (Fujisawa et al., 1992), Lactobacillus rhamnosus GG (ATCC 53103; Miettinen et al., 1996; Peña \& Versalovic, 2003; Tao et al., 2006), Lactobacillus paracasei E506 and Lactococcus lactis subsp. cremoris E523 (Miettinen et al., 1996) have been described. The bacteria were cultivated overnight at $37^{\circ} \mathrm{C}$ in static MRS broth (Difco; BD Biosciences). After cultivation, the bacteria were collected, washed with phosphate buffered saline (PBS), pH 7.1, and used for the assays. For analysing lactobacillar cell-free extracellular material, washed cells were incubated in PBS at $37^{\circ} \mathrm{C}$ for $1-5 \mathrm{~h}$. After incubation, cells were removed by centrifuging, and the PBS supernatant was filtered through a $0.45 \mu \mathrm{m}$ membrane.

Cloning, overproduction and purification of recombinant GAPDH and enolase. The primers for amplification of internal sequences of L. crispatus ST1 gap and eno genes were designed on the basis of the gap gene in Lactococcus lactis subsp. lactis III403 (Bolotin et al., 2001) and the eno gene in L. johnsonii NCC 533 (Pridmore et al., 2004; locus tag LJ1416). The amplicons were sequenced by using an ABI PRISM 310 Genetic Analyser (Perkin Elmer Life and Analytical Sciences), and the information was then used in sequencing the entire eno and gap genes from the chromosomal DNA of L. crispatus ST1. Genes encoding L. crispatus ST1 GAPDH and enolase were cloned into the pQE30 expression system (Qiagen) for expression as $\mathrm{N}$-terminal $\mathrm{His}_{6}$-fusions, which were purified by the Qiaexpress Protein Purification System (Qiagen) under non-denaturing conditions. The purified proteins were extensively dialysed against PBS before use.

Subcellular localization of enolase and GAPDH. Antisera against the purified $\mathrm{His}_{6}-\mathrm{GAPDH}$ and $\mathrm{His}_{6}$-enolase of ST1 were raised in rabbits using routine immunization procedures (Medprobe, Viikki Laboratory Animal Center, University of Helsinki). Preimmunization serum was collected before primary immunization. For immunoelectron microscopy (IEM), IgG molecules were purified from the preimmune and the hyperimmune sera by affinity chromatography using Protein A Sepharose CL-4B (Pharmacia LKB Biotechnology). For studying the extracellular GAPDH and enolase, the cell-free extracellular material from $3 \times 10^{8}$ bacteria was precipitated with trichloroacetic acid after incubating cells at $37^{\circ} \mathrm{C}$ for $5 \mathrm{~h}$; the proteins were then separated by electrophoresis in $12 \%(\mathrm{w} / \mathrm{v})$ SDS-PAGE gels and transferred onto $0.2 \mu \mathrm{m}$ nitrocellulose membrane for Western blotting with the anti-His ${ }_{6}$-enolase and the 
anti-His ${ }_{6}$-GAPDH antibodies. As a marker for a cytoplasmic peptide (Alvarez et al., 2003), IgG specific for the RNA polymerase $\beta 1$-subunit (NeoClone) was used. For cell lysis, ST1 cells in $1 \mathrm{ml}$ PBS were treated with mutanolysin $\left(50 \mathrm{U} \mathrm{ml}^{-1}\right.$; Sigma Aldrich) and lysozyme (20 mg ml ${ }^{-1}$; Roche Diagnostics) at $37^{\circ} \mathrm{C}$ for $2 \mathrm{~h}$; cells were then lysed by boiling for $20 \mathrm{~min}$. Lysate from $3 \times 10^{8}$ cells was used for Western blotting, and the relative amounts of enolase and GAPDH in the cell and supernatant samples were assessed using the TINA 2.0 program (Isotopenmessgeräde). Localization of GAPDH and enolase on the surface of $L$. crispatus ST1 was studied by routine post-embedding IEM labelling methods. The washed bacteria were immediately fixed in $0.1 \mathrm{mM}$ sodium acetate buffer ( $\mathrm{pH} 5.0$ ) containing $4 \%(\mathrm{w} / \mathrm{v})$ paraformaldehyde and $0.1 \%$ glutaraldehyde for $2 \mathrm{~h}$ at room temperature and washed with sodium acetate buffer prior to embedding into LR-White resin. After polymerization, ultrathin sections were cut and collected onto carbon-coated 200mesh nickel grids. Sections were incubated on drops of diluted $\left(1: 30\right.$ in PBS) anti-His ${ }_{6}$-GAPDH-IgG and anti-His ${ }_{6}$-enolase-IgG containing $2 \%(\mathrm{w} / \mathrm{v})$ bovine serum albumin (BSA; Sigma, Aldrich), $0.1 \%$ Tween 20 and $0.1 \%$ fish skin gelatin (Sigma Aldrich) in $0.1 \mathrm{M}$ sodium phosphate buffer ( $\mathrm{pH} 7.1$ ) for $3.5 \mathrm{~h}$ at room temperature, and were then washed five times in sodium phosphate buffer prior to incubation on drops of $1: 80$ diluted protein A colloidal gold (10 $\mathrm{nm}$ in size) for $30 \mathrm{~min}$. After washing, the sections were poststained in uranyl acetate and lead citrate before examination in a JEOL EXII transmission electron microscope. For enzyme activity measurements, extracellular material from $5 \times 10^{9}$ bacteria was used after incubating cells in $50 \mathrm{mM}$ Tris/ $\mathrm{HCl}\left(\mathrm{pH} \mathrm{8.0)}\right.$ at $37^{\circ} \mathrm{C}$ for $2 \mathrm{~h}$. The GAPDH activity was measured as described by Pancholi \& Fischetti (1992). The enolase activity was measured by coupled assay (Pancholi \& Fischetti, 1998) using 3-phosphoglycerate (Fluka Chemie) as substrate and phosphoglycerate mutase for converting substrate to 2-phosphoglycerate in $50 \mathrm{mM}$ Tris/HCl ( $\mathrm{pH} \mathrm{8.0)}$. The reactions were allowed to occur for $15 \mathrm{~min}$.

Binding and activation of plasminogen. The tPA- and uPAmediated activation of Plg in the presence of bacteria or bacterial components was measured essentially as described by Lähteenmäki et al. (1995). Briefly, cell-free extracellular material from $3 \times 10^{8}$ bacteria, bacterial cells, or recombinant $\mathrm{His}_{6}-\mathrm{GAPDH}$ and $\mathrm{His}_{6}$-enolase (both $137 \mathrm{nM}$ ) were incubated with $4 \mu \mathrm{g}$ human or bovine Glu-Plg (American Diagnostica), 2 ng tPA (Biopool) or uPA (American Diagnostica) and $0.45 \mathrm{mM}$ chromogenic substrate of plasmin S2251 (Kabivitrum) in a final volume of $200 \mu \mathrm{l}$, and increase in plasmin activity was assessed at intervals by measuring absorbance at $405 \mathrm{~nm}$. In inhibition tests, $4 \mu \mathrm{g} \alpha_{2} \mathrm{AP}$ (Calbiochem), 0.09 TIU aprotinin (Sigma Aldrich) or $1 \mathrm{mM} \varepsilon$-aminocaproic acid (EACA; Sigma Aldrich) were included. The proportions of bacterium-bound plasmin activity and plasmin activity in the supernatant were determined by incubating $3 \times 10^{8}$ bacteria in PBS with Plg and tPA for $5 \mathrm{~h}$ at $37^{\circ} \mathrm{C}$ in the presence or absence of $\alpha_{2} \mathrm{AP}$. After incubation, the cells and the supernatant were separated, the cells were washed once with PBS, and both fractions were incubated for $3 \mathrm{~h}$ in a final volume of $200 \mu \mathrm{l} \mathrm{PBS}$ containing $0.45 \mathrm{mM} \mathrm{S}$-2251. For analysing protection from $\alpha_{2} \mathrm{AP}$, plasmin (109 nM; Fluka Chemie) was incubated with the ST1 extracellular material for $15 \mathrm{~min}$ at room temperature prior to adding S-2251 and $\alpha_{2} \mathrm{AP}$ in increasing concentrations. Plasmin activity was measured after $1 \mathrm{~h}$ incubation at $37^{\circ} \mathrm{C}$.

Binding of ${ }^{125} \mathrm{I}$-labelled Plg, plasmin and tPA on the bacterial surface was tested essentially as described by Kukkonen et al. (1998). After labelling with ${ }^{125} \mathrm{I}$ (Amersham Biosciences), the specific activities obtained were $3.5 \times 10^{6}$ c.p.m. $\mu \mathrm{g}^{-1}$ for Glu-Plg, $1.0 \times 10^{6}$ c.p.m. $\mu \mathrm{g}^{-1}$ for plasmin and $2.6 \times 10^{6}$ c.p.m. $\mu g^{-1}$ for tPA. Bacteria $\left(2 \times 10^{9}\right.$ cells $)$ were incubated for $2 \mathrm{~h}$ at $37{ }^{\circ} \mathrm{C}$ with $20 \mathrm{ng}{ }^{125} \mathrm{I}$-labelled Plg, plasmin, or $\mathrm{tPA}$ in the presence or absence of $4 \mathrm{mM}$ EACA in a volume of $500 \mu \mathrm{l}$. Bacteria were collected, washed twice with PBS and the bound radioactivity was measured. For analysing binding of Plg and plasmin as well as conversion of Plg to plasmin on the surface of ST1, bacteria $\left(1.6 \times 10^{8}\right.$ cells in $\left.100 \mu \mathrm{l} \mathrm{PBS}\right)$ were incubated for $5 \mathrm{~h}$ at $37^{\circ} \mathrm{C}$ with $10 \mu \mathrm{g}$ Plg in the presence or absence of $5 \mathrm{ng} \mathrm{tPA}$, or with $10 \mu \mathrm{g}$ plasmin. After incubation, the cells and the supernatant were separated, the cells were washed once, and both fractions were analysed by Western blotting with anti-Plg IgG (American Diagnostica) and secondary antibodies.

The binding of Plg and plasmin to extracellular material from $3 \times 10^{8}$ bacteria as well as to purified $\mathrm{His}_{6}$-GAPDH and $\mathrm{His}_{6}$-enolase (tested at $180 \mathrm{nM}$ ) was measured by time-resolved fluorometry as described by Kukkonen et al. (1998). Briefly, polystyrene microtitre plates were coated in PBS with extracellular material, enolase, GAPDH, or the Slayer protein from L. crispatus ST1; the latter was purified with guanidine hydrochloride as described by Antikainen et al. (2002). Laminin-coated surface was used as a positive control for Plg binding. One microgram of Plg or plasmin was added in $100 \mu \mathrm{PBS} / 0.1 \%$ Tween 20, in the presence or absence of $10 \mathrm{mM}$ EACA. For detection of the binding, anti-Plg IgG (720 ng per well) and $\mathrm{Eu}^{3+}$-labelled antirabbit IgG (80 ng per well; PerkinElmer Life and Analytical Sciences) were used. For analysing proteolytic cleavage and release of enolase and GAPDH from the cell surface, ST1 cells $\left(2 \times 10^{9} \mathrm{ml}^{-1}\right)$ were incubated with $20 \mu \mathrm{g}$ plasmin $\mathrm{ml}^{-1}$ for $5 \mathrm{~h}$ at $37^{\circ} \mathrm{C}$. The cells were removed and the supernatant was analysed by Western blotting with anti-His $6^{-}$ enolase and anti-His ${ }_{6}$-GAPDH IgGs.

\section{RESULTS}

\section{Cellular location of enolase and GAPDH in $L$. crispatus ST1}

To detect the extracellular proteome in L. crispatus ST1, peptides released from ST1 cells into PBS were analysed by SDS-PAGE and Western blotting. Washed ST1 cells were suspended into PBS and incubated for $5 \mathrm{~h}$ at $37^{\circ} \mathrm{C}$, the cells were pelleted, and the supernatant was filtered to completely remove any remaining cells. The major extracellular peptides detectable by Coomassie blue staining (Fig. 1a) included a peptide of $47 \mathrm{kDa}$ in apparent molecular mass and a peptide of $38 \mathrm{kDa}$. The $38 \mathrm{kDa}$ peptide was excised from the gel and its N-terminal amino acid sequence was determined. The sequence obtained, TVKIGINGFGRIGRLAFRRI, has $85-100 \%$ identity with the amino-terminal sequence of GAPDHs sequenced from species of Lactobacillus and Lactococcus (Altermann et al., 2005; Bolotin et al., 2001; Kleerebezem et al., 2003; Pridmore et al., 2004). In Western blotting, this peptide reacted with the antiserum raised against $\mathrm{His}_{6}$-GAPDH cloned from ST1 and purified from recombinant $E$. coli (Fig. 1a; see below), giving further proof that the peptide indeed was GAPDH. Enolase is another glycolytic enzyme detected on the bacterial surface, and we indeed identified the $47 \mathrm{kDa}$ peptide as enolase by immunoblotting with specific antisera raised against enolase from Streptococcus pneumoniae (Bergmann et al., 2001) as well as against the $\mathrm{His}_{6}$-enolase cloned from ST1 and purified from recombinant $E$. coli in this study (Fig. 1a; see below for cloning details).

Western blotting analysis of enolase and GAPDH in the supernatant over time revealed a gradual incease in their amounts (Fig. 1b). After $5 \mathrm{~h}$ incubation, the amounts of 
(a)

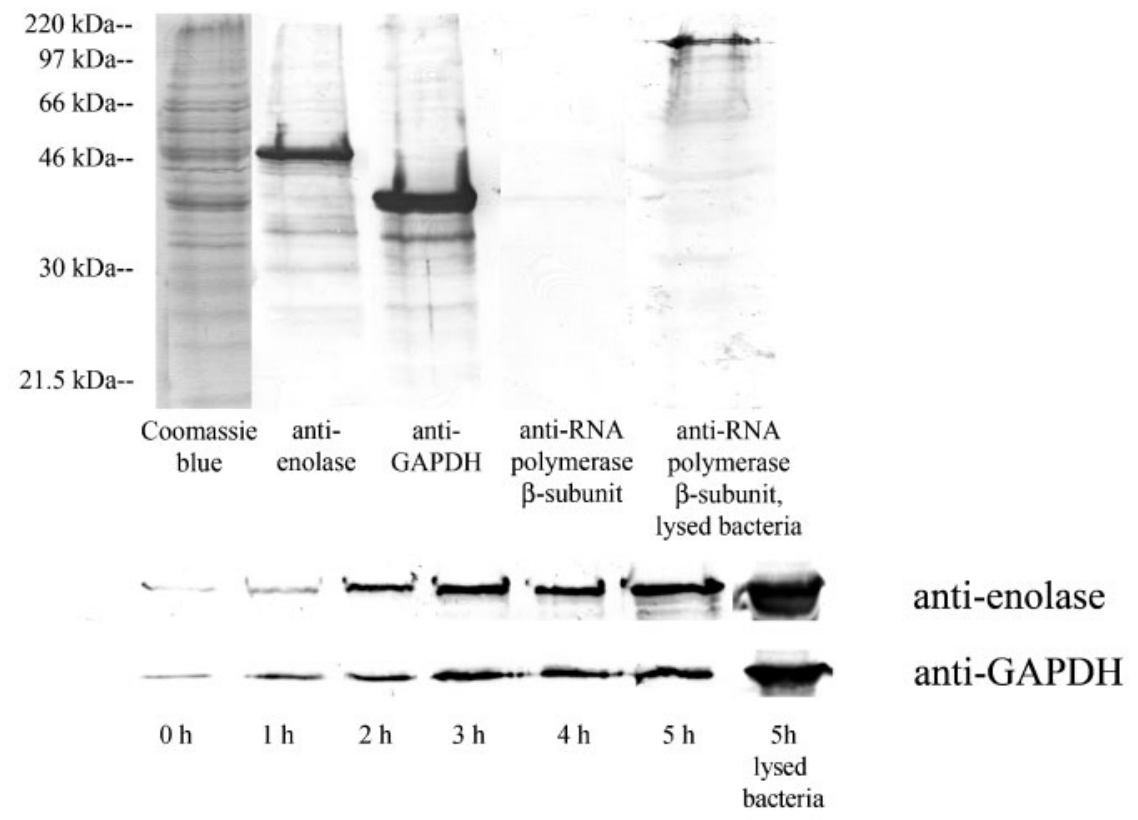

(c)

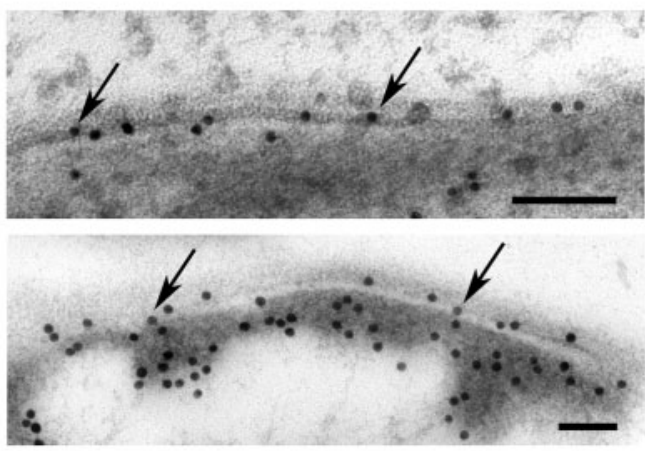

Hyperimmune sera

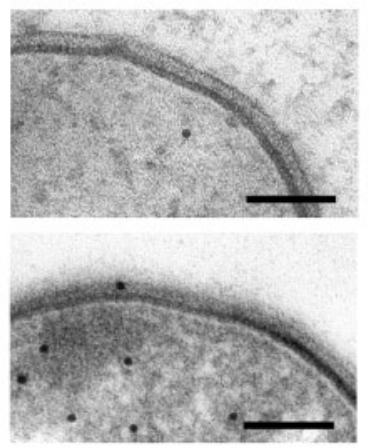

Preimmune sera
anti-GAPDH

anti-enolase

Fig. 1. Subcellular localization of GAPDH and enolase in L. crispatus ST1. (a) Extracellular proteins of L. crispatus ST1 cells incubated in PBS for $5 \mathrm{~h}$. Peptides released from $3 \times 10^{8}$ cells were precipitated with trichloroacetic acid and detected in Coomassie-stained SDS-PAGE as well as by Western blotting with lgGs raised against enolase, GAPDH or RNA-polymerase $\beta$-subunit; the latter was used to detect possible cell lysis. (b) Time-course of the release of enolase and GAPDH into PBS. Washed L. crispatus ST1 cells were suspended into PBS, and the $0 \mathrm{~h}$ sample of the buffer for Western blotting was taken immediately. The other time points are indicated. For comparison, detection of enolase and GAPDH in bacterial cells lysed after the $5 \mathrm{~h}$ incubation are shown on the right. (c) IEM images of localization of GAPDH and enolase in washed ST1 cells. The detection was post-cutting using anti-His ${ }_{6}-\mathrm{GAPDH}$ and anti-His ${ }_{6}$-enolase IgGs and protein A-gold particles. The arrows indicate binding to the cell wall. Reactivity of IgGs from the hyperimmune and the preimmune sera is shown. Bars, $100 \mathrm{~nm}$.

enolase and GAPDH in the supernatant were $22 \%$ and $20 \%$ of their amounts in lysed cell samples. During the $5 \mathrm{~h}$ incubation, the $\mathrm{pH}$ of the buffer changed from 7.1 to 6.8 , indicating that the bacteria had a weak metabolic activity in PBS, and the number of viable cells slightly decreased from $5 \times 10^{8}$ to $3 \times 10^{8} \mathrm{ml}^{-1}$. No viable cells were recovered upon cultivation of $100 \mu \mathrm{l}$ samples from the filtered buffers. Microscopic examination of the cell suspensions did not reveal detectable cell lysis or cell damage after the $5 \mathrm{~h}$ incubation, neither did we detect DNA in the cell-free buffer (data not shown). Furthermore, the cytoplasmic marker protein RNA polymerase $\beta 1$-subunit (Alvarez et al., 2003) was detectable in the lysed cell sample but not in the cell-free buffer (Fig. 1a). Enolase and GAPDH enzymic activities were detected in the cell-free extracellular material (data not shown). Next, we used IgGs raised against $\mathrm{His}_{6}$-enolase and $\mathrm{His}_{6}-\mathrm{GAPDH}$ (see below) in IEM of washed ST1 cells. Both IgGs bound to antigens in the cytoplasm as well as in the cell wall, and the binding of IgGs from the preimmune sera was significantly poorer (Fig. 1c). In particular, IEM revealed that a fraction of enolase and GAPDH antigens are within or in close proximity to the cell membrane (Fig. 1c). It was 

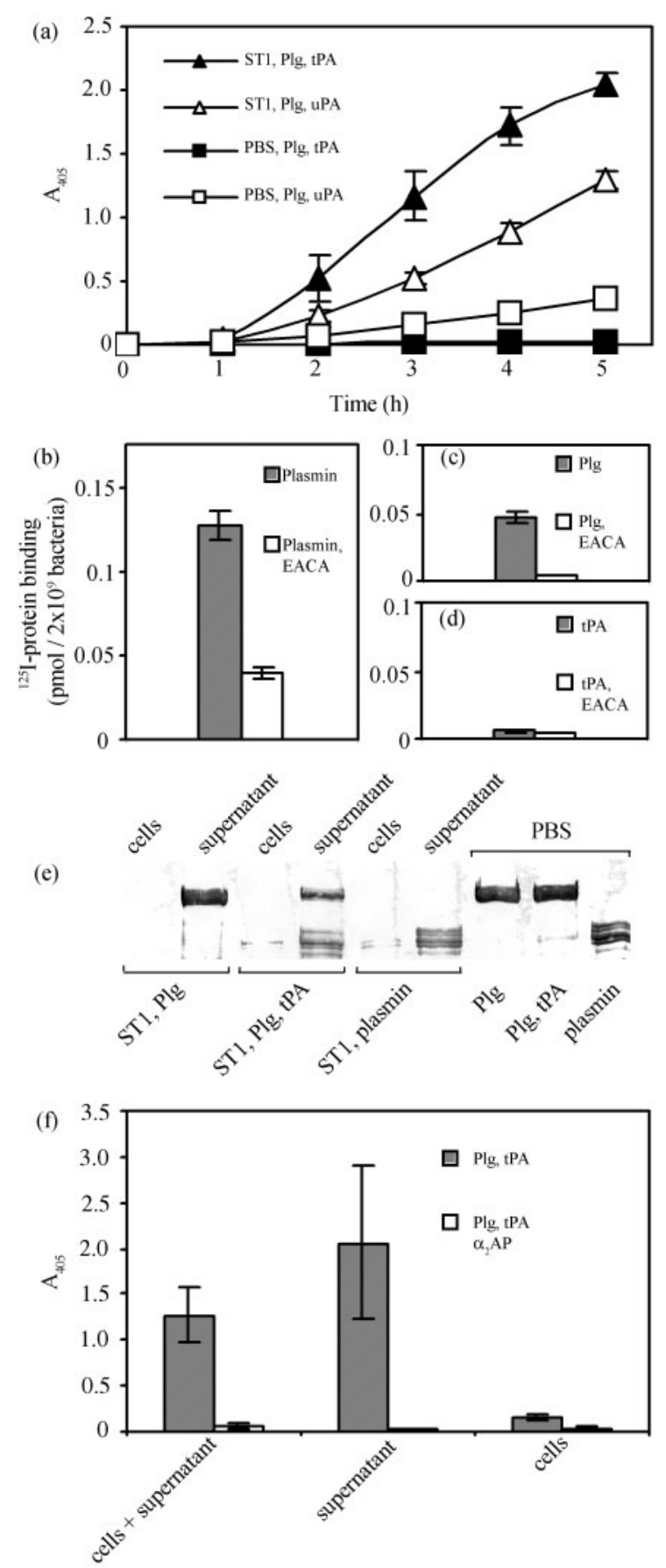

concluded that enolase and GAPDH of L. crispatus ST1 are present in the cellular cytoplasm and in the cell wall and also represent major components in the extracellular proteome of $L$. crispatus ST1.

\section{Interaction of Plg by the extracellular material from $L$. crispatus ST1}

Considering that streptococcal enolase and GAPDH bind $\mathrm{Plg}$, we next assessed the Plg receptor function in ST1 cells and in the material released into PBS. Washed ST1 cells
Fig. 2. Binding and conversion of Plg and plasmin by L. crispatus ST1 cells. (a) Kinetic measurement of Plg activation in the presence of ST1 cell suspension $\left(4 \times 10^{7}\right.$ cells). Plg with tPA $(\mathbf{\Delta})$ or uPA $(\triangle)$ was incubated with ST1 cells, and the formation of plasmin activity was measured using the chromogenic substrate of plasmin. (b-d) Binding of (b) ${ }^{125}$ I-plasmin, (c) ${ }^{125}$ I$\mathrm{Plg}$ and (d) ${ }^{125} \mathrm{I}$-tPA to ST1 cells. Bacteria were incubated with ${ }^{125} \mathrm{I}$-labelled protein in the absence (grey columns) or presence (open columns) of the lysine analogue EACA. (e) The conversion of the single-chain Plg to the two-chain plasmin in the presence or absence of ST1 cells and tPA. The bacteria $\left(1.6 \times 10^{8}\right.$ cells) were incubated with $\mathrm{Plg}$ in the presence or absence of tPA, or with plasmin for $5 \mathrm{~h}$. The cells and supernatant were separated and Plg and plasmin were analysed from both fractions by Western blotting using anti-Plg antibodies. ( $f$ ) Distribution of plasmin activity between cells and buffer. Bacteria $\left(3 \times 10^{8}\right.$ cells $)$ were incubated in PBS with Plg and tPA for $5 \mathrm{~h}$, the cells and the supernatant were separated, and both fractions were incubated with chromogenic substrate of plasmin. Plasmin activity was measured at $3 \mathrm{~h}$. The means and standard deviations from two independent assays with quadruplicate samples in (a) and (f) and with triplicate samples in (b), (c) and (d) are shown.

enhanced activation of human Plg by both tPA and uPA (Fig. 2a); the effect on tPA-mediated activation was clearer than that on uPA-mediated catalysis, and no Plg activation by tPA was seen in the absence of ST1 cells (Fig. 2a). The enhancement of tPA-mediated activation of bovine Plg was similar to that of human Plg (data not shown). The surface association of the plasmin generated in the presence of ST1 cells was then assessed by three approaches: (i) by analysing the binding of radiolabelled Plg, plasmin and tPA onto ST1 cells, (ii) by analysing the conversion of the single-chain $\mathrm{Plg}$ molecule into the two-chain plasmin, and (iii) by determining the distribution of plasmin enzymic activity between cells and buffer.

The binding of ${ }^{125} \mathrm{I}$-plasminogen, ${ }^{125} \mathrm{I}$-plasmin, and ${ }^{125} \mathrm{I}$-tPA onto the surface of washed $L$. crispatus ST1 cells was assessed using conditions commonly used with pathogenic bacteria by us and others (Bergmann et al., 2001; Kukkonen et al., 1998; Kuusela \& Saksela, 1990; Lähteenmäki et al., 1995; Pancholi \& Fischetti, 1992). The level of Plg binding onto ST1 cells was low, in independent assays corresponding to $1-3 \%$ of the added amount of Plg (Fig. 2c), whereas the binding of plasmin was approximately two- to threefold higher (Fig. 2b). Radiolabelled tPA showed only neglible binding onto ST1 cells (Fig. 2d). The binding of both plasmin and Plg onto ST1 cells was significantly inhibited by EACA (Fig. 2b, c). EACA is a lysine analogue and an inhibitor of kringle-mediated binding of $\mathrm{Plg} /$ plasmin onto receptor or cofactor molecules. These results indicated that Plg binds to ST1 cells in a lysine-dependent manner, which indicates involvement of the kringle domains. However, the observed binding level is low, and a better binding occurs with plasmin, which indeed is known to have a higher affinity than Plg to lysine-containing targets (Kuusela \& Saksela, 1990). 
The conversion of the single-chain plasminogen into the two-chain plasmin in the presence or absence of ST1 cells and tPA was then assessed. The suspensions were incubated for $5 \mathrm{~h}$, the cells and the buffer were separated, and Plg and plasmin were analysed from both fractions by Western blotting. The assay showed that the presence of ST1 cell suspension enhanced the tPA-catalysed conversion of Plg into plasmin (Fig. 2e). In assays lacking tPA, no binding of Plg onto ST1 cells was observed, and Plg was detected only in the buffer (Fig. 2e). When tPA was added with Plg and ST1 cells, generation of plasmin as well as its partial immobilization onto the bacterial cells were observed; however, most of the plasmin formed was present in the cell-free supernatant (Fig. 2e). In accordance with this observation, a small amount of exogenously added plasmin was immobilized onto the ST1 cells (Fig. 2e). To confirm the results on Plg conversion, we assessed the relative amounts of plasmin enzymic activity on bacterial surface and in the buffer after a $5 \mathrm{~h}$ incubation of washed ST1 cells with Plg and tPA. The bacterial suspension enhanced plasmin formation, and after fractionation of the suspension into the cells and the buffer, $92 \%$ of the formed plasmin activity was detected in the cellfree supernatant (Fig. 2f). The plasmin formed was nearly completely inhibited by $\alpha_{2} \mathrm{AP}$ (Fig. 2f). Similar fractionation after shorter incubation times (1,2 and $3 \mathrm{~h}$ ) in PBS revealed a gradual enrichment of plasmin formation in the buffer and a decrease in cell-associated plasmin (data not shown), which is in agreement with the gradual release of the extracellular material from ST1 cell surface (Fig. 1b).

We next measured binding of Plg and plasmin onto the extracellular material and, secondly, its capacity to enhance $\mathrm{Plg}$ activation. The extracellular proteome of ST1 efficiently bound plasminogen and plasmin as well as enhancing tPAand uPA-catalysed plasminogen activation (Fig. 3a, b). EACA reduced the observed binding of plasminogen by $93 \%$ and plasmin by $80 \%$, and the plasmin activity formed was also undetectable in the presence of EACA (data not shown). These observations indicate that the extracellular material of ST1 cells expresses Plg activation cofactor function, i.e. it binds Plg in a lysine-sensitive manner and enhances plasmin formation by tPA. An important property of $\mathrm{Plg}$ receptors or cofactors is that binding to them protects the forming plasmin from $\alpha_{2}$ AP. Plasmin $(109 \mathrm{nM})$ was incubated for $15 \mathrm{~min}$ with the ST1 supernatant and its activity was subsequently assessed in the presence of increasing amounts of $\alpha_{2} \mathrm{AP}$ (Fig. 3c). A low level of protection was seen; at $\alpha_{2} \mathrm{AP}$ concentrations of $72 \mathrm{nM}$ and $144 \mathrm{nM}$, plasmin activity with the extracellular material was $18 \%$ and $44 \%$ higher than in PBS alone $(P<0.05)$, whereas at a lower concentration of $\alpha_{2} \mathrm{AP}$ the difference between the samples was not statistically significant.

\section{Characterization of enolase and GAPDH of $L$. crispatus ST1}

The published genomic sequences of lactococci and lactobacilli each contain a gap gene encoding GAPDH proteins sharing $80-90 \%$ amino acid sequence identity. (a)

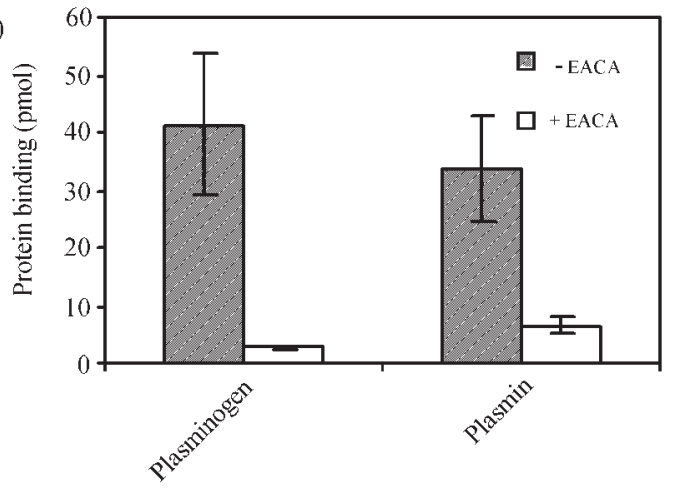

(b)

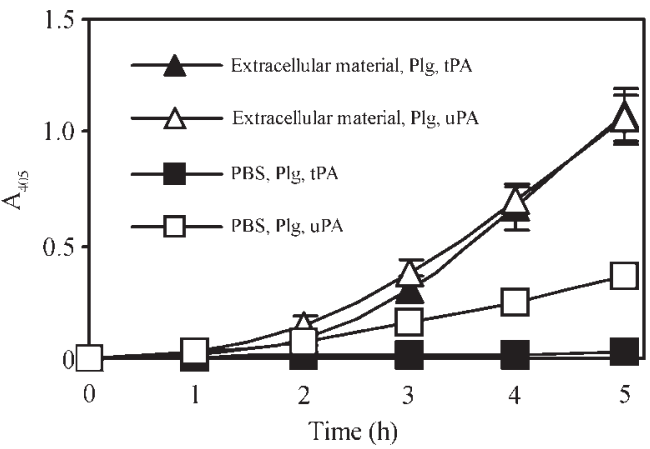

(c)

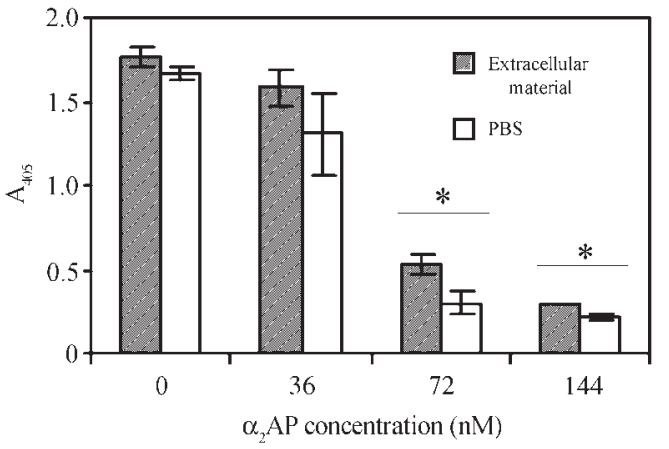

Fig. 3. Interaction of extracellular material from $L$. crispatus ST1 with Plg and plasmin. (a) The binding of Plg and plasmin to the cell-free extracellular material from $3 \times 10^{8}$ cells in the absence (grey columns) or presence (open columns) of EACA was measured by time-resolved fluorometry with anti-Plg $\lg G$ and $\mathrm{Eu}^{3+}$-labelled secondary immunoglobulins. The means and standard deviations from two independent assays with quadruplicate samples are shown. (b) Enhancement of Plg activation. Plg with tPA $(\boldsymbol{\Delta})$ or uPA $(\triangle)$ was incubated with the extracellular material from $3 \times 10^{8}$ cells. The means and standard deviations from two independent assays with quadruplicate samples are shown. (c) Protection of plasmin from $\alpha_{2}$ AP. Plasmin was incubated in the absence (open columns) or presence (grey columns) of extracellular material from $1.5 \times 10^{8}$ ST1 cells prior to adding the $\alpha_{2} \mathrm{AP}$ and a chromogenic substrate of plasmin. Means and standard deviations from two independent assays with triplicate samples are shown. An asterisk indicates that the difference between the two test samples was statistically significant $(P<0.05$; Student's two-tailed $t$-test). 
(a)

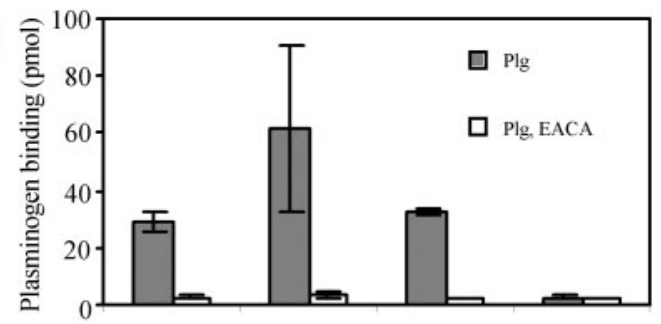

(b)

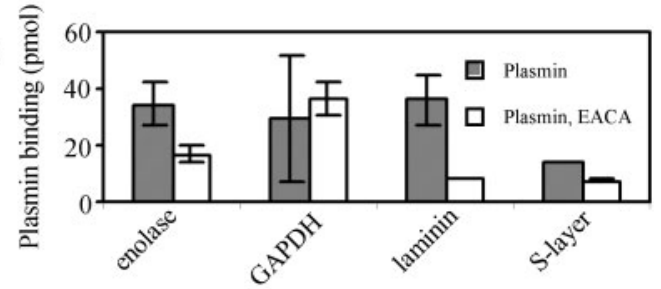

(c)

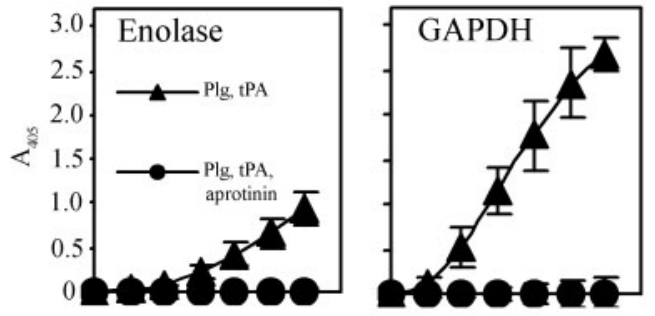

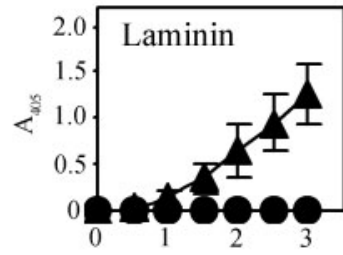

Time (h)

(d)

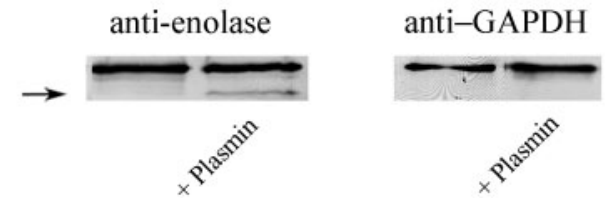

Enolases in lactobacilli are more variable; eno genes per strain vary between 1 and 3 in number and the overall sequence identity of the proteins is between 47 and $93 \%$. We amplified internal sequences of gap and eno of ST1 using primers designed according to the sequences of enolase genes in L. johnsonii NCC 533 (Pridmore et al., 2004) and gap of Lactococcus lactis subsp. lactis Il1403 (Bolotin et al., 2001). The internal DNA amplicons were sequenced, and to obtain the correct $5^{\prime}$ and $3^{\prime}$ termini of the ORFs, the complete ORFs of eno and gap were sequenced from the ST1 genome. The ORF of ST1 gap (EMBL AJ849470) encodes a protein of 338 amino acids with $88 \%$ sequence identity to GAPDHs of L. johnsonii (Pridmore et al., 2004) and L. acidophilus (Altermann et al., 2005). The predicted sequence of ST1 enolase (EMBL AJ849471) is 428 amino acids long and $94 \%$ identical to the enolase of L. acidophilus
Fig. 4. Interaction of $L$. cripatus $\mathrm{ST} 1 \mathrm{His}_{6}$-enolase and $\mathrm{His}_{6}{ }^{-}$ GAPDH with human Plg. The binding of Plg (a) and plasmin (b) to the purified recombinant proteins in the absence (grey columns) or in the presence (open columns) of EACA was measured by time-resolved fluorometry using anti-Plg $\lg G$ and $\mathrm{Eu}^{3+}$-labelled secondary antibodies. The binding of Plg and plasmin to their known protein target laminin as well as to the S-layer protein of L. crispatus ST1 is also shown. The means and standard deviations from two independent assays with quadruplicate samples are shown. (c) Enhancement of tPA-catalysed plasmin formation by $\mathrm{His}_{6}$-enolase and $\mathrm{His}_{6}-\mathrm{GAPDH}$. $\mathrm{Plg}$ and tPA were incubated with the recombinant proteins, and plasmin activity was measured using a chromogenic substrate of plasmin. The plasmin formation was tested in the absence $(\boldsymbol{A})$ or presence $(\boldsymbol{O})$ of the serine protease inhibitor aprotinin. As a control, plasmin formation with laminin as well as with the S-layer protein isolated from L. crispatus ST1 are shown. The means and standard deviations from two independent assays with quadruplicate samples are shown. (d) Release of enolase and GAPDH from cells in the absence or presence of plasmin during a $5 \mathrm{~h}$ incubation. Enolase and GAPDH were detected by Western blotting with specific antibodies. The minor degradation product of enolase is marked with an arrow on the left.

(Altermann et al., 2005). Both genes were cloned from the ST1 genome into the vector pQE30 and expressed in E. coli M15. The $\mathrm{N}$-terminal $\mathrm{His}_{6}$-tagged fusion proteins were purified from E. coli M15 under non-denaturing conditions and tested for plasminogen receptor activity. Both proteins exhibited an EACA-inhibitable binding of Plg (Fig. 4a) and bound plasmin (Fig. 4b), as well as enhanced tPA- (Fig. 4c) and uPA- (data not shown) catalysed Plg activation. Binding of plasmin to enolase and to the control protein laminin was inhibited by EACA, which, however, did not diminish binding to GAPDH (Fig. 4b). A major surface protein of $L$. crispatus ST1, the S-layer, showed only poor binding of Plg and enhancement of its activation (Fig. 4). The serine protease inhibitor aprotinin inhibited the activity, indicating that the substrate cleavage was by plasmin and not by enolase or GAPDH. The observed release of plasmin from the ST1 cell surface might involve plasmin proteolysis, which could cleave or release Plg receptor molecules from the ST1 surface, or alternatively, cryptic terminal lysines may become exposed after cleavage. We therefore analysed the release of enolase and GAPDH from ST1 cells in the absence and presence of added plasmin. Presence of active plasmin did not affect the amounts of enolase or GAPDH in the buffer; a limited degradation of enolase, however, was detected (Fig. 4d). This indicates that plasmin proteolysis does not affect the detachment of enolase and GAPDH from the L. crispatus ST1 cell surface and that these proteins are poor substrates for plasmin proteolysis.

\section{Enhancement of Plg activation by extracellular material from other lactic acid bacteria}

The available genomic sequences of lactobacilli and lactococci reveal the presence of enolase and GAPDH 
genes that are variably related to those of $L$. crispatus ST1. $L$. crispatus is of the DNA homology group A2 in the Acidophilus group of lactobacilli (Johnson et al., 1980). Extracellular proteins in PBS were prepared from five strains of Lactobacillus representing the DNA homology groups (Johnson et al., 1980) A1 (L. acidophilus E507), A3 (L. amylovorus JCM 5807), A4 (L. gallinarum T-50), B1 (L. gasseri JCM 1130/ATCC 19992) and B2 (L. johnsonii F133) as well as three strains in probiotic or dairy use ( $L$. rhamnosus GG, L. paracasei E506 and Lactococcus lactis E523). The extracellular proteins were screened for enhancement of tPA- and uPA-catalysed Plg activation and analysed by Western blotting for possible presence of enolase and GAPDH (Fig. 5). The extracellular preparations exhibited variable capacity to enhance tPA- and uPAcatalysed Plg activation, with L. gallinarum T-50 (A4) and L. johnsonii F133 (B2) showing the highest and L. amylovorus JCM 5807 (A3), L. gasseri JCM 1130/ATCC 19992 (B1) and L. rhamnosus GG the lowest activity (Fig. 5a). The preparations from L. acidophilus E507, L. paracasei E506 and Lactococcus lactis E523 gave similar activity as the preparation from $L$. crispatus ST1. No plasmin activity was detected in absence of tPA or uPA, and a highly similar pattern of Plg activation was seen when bacterial cell suspensions were tested (data not shown). Anti-His $6^{-}$ enolase and anti-His ${ }_{6}-\mathrm{GAPDH}$ antibodies detected crossreactive peptides in five and seven, respectively, of the protein preparations (Fig. 5b). SDS-PAGE analysis of the proteins revealed variable amounts of peptides with apparent molecular masses of enolase and GAPDH in all preparations (Fig. 5c).

\section{DISCUSSION}

The interaction of L. crispatus with human/mammalian Plg here described represents a novel host interaction for Lactobacillus, and our results give further evidence for a role of extracellular proteins in Lactobacillus-host interactions. The intestinal commensal and opportunistic pathogen Bacteroides fragilis was recently shown to bind $\mathrm{Plg}$ (Sijbrandi et al., 2005), and our results extend Plg interaction to commensal lactic acid bacteria as well. These results suggest that Plg interaction with bacteria is more common than so far expected (Lähteenmäki et al., 2005). The enhancement of Plg activation by L. crispatus ST1 was associated mainly with the extracellular proteins

(a)

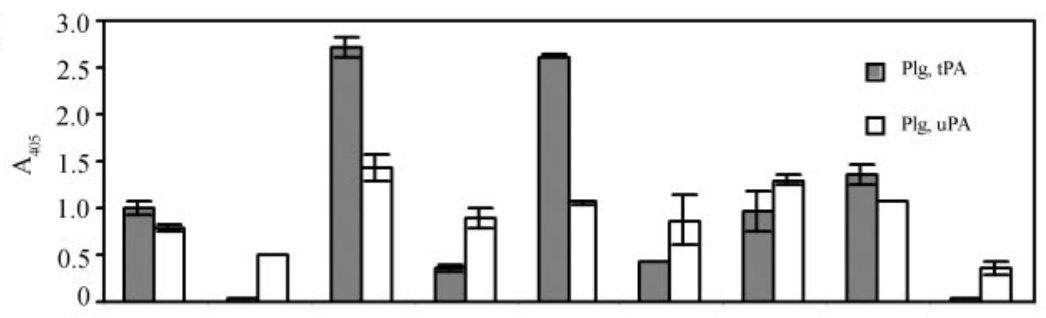

(b)
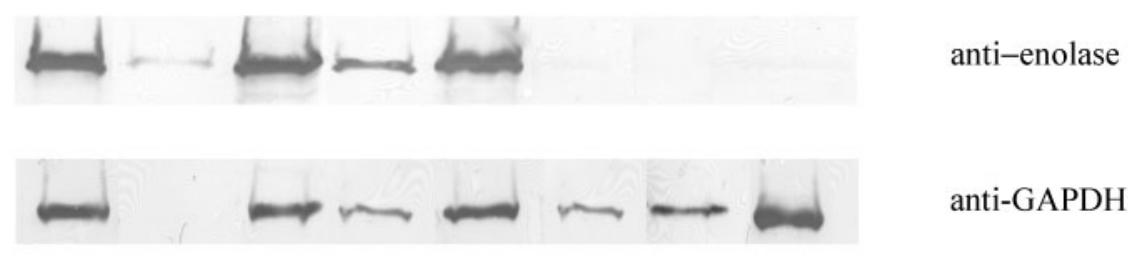

anti-GAPDH

(c)

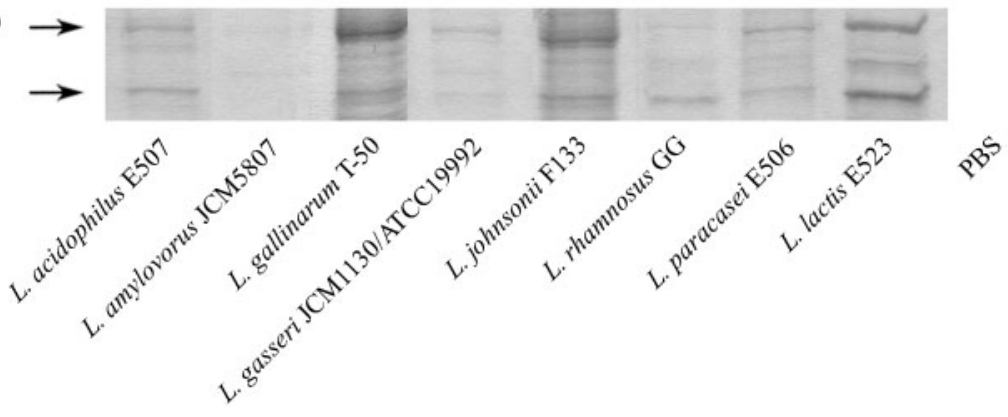

Coomassie blue

Fig. 5. Extracellular Plg cofactor function, enolase and GAPDH in lactic acid bacteria. (a) Enhancement of tPA- and uPAcatalysed Plg activation by the extracellular material from $3 \times 10^{8}$ cells analysed, at $5 \mathrm{~h}$ after adding the chromogenic substrate. (b) Identification of enolase and GAPDH in the extracellular material by Western blotting with specific antibodies; in (c), the corresponding Coomassie blue-stained SDS-PAGE gel is shown. The migration distances of enolase and GAPDH are marked with arrows on the left, and the bacterial strains are given at the bottom. 
gradually released from the bacterial surface. This is in sharp contrast to $\mathrm{Plg}$ activation by Gram-positive bacterial pathogens which immobilize Plg/plasmin on their surface (Lähteenmäki et al., 2001, 2005). The system here described is close to the one shown by Streptococcus pyogenes, whose surface enolase, in a purified form, enhances Plg activation by tPA but protects the plasmin formed only partially from inhibition by $\alpha_{2} \mathrm{AP}$. By contrast, plasmin generated by streptokinase is fully protected from inhibition (Derbise et al., 2004; Pancholi \& Fischetti, 1998). In this respect, the main differences between streptococci and L. crispatus are the extracellular location of enolase and lack of streptokinaselike PA activity in L. crispatus. It is likely that lactobacillusmediated Plg activation results in locally restricted plasmin proteolysis. So far, plasmin activity in relation to lactobacilli has been studied for fermentation quality in cow milk (Bastian \& Brown, 1996); in this context it is noteworthy that L. crispatus ST1 also enhanced activation of bovine Plg.

Several lines of evidence indicate that enhancement of Plg activation by $L$. crispatus involves mainly extracellular proteins. (i) Binding of plasmin and in particular of Plg onto ST1 cells was poor; we detected levels of $2-2.5 \%$ in plasminogen binding and 5.5-6.3\% in plasmin binding, which under similar assay conditions with pathogens have been up to $78 \%$ (Ullberg et al., 1990, 1992). (ii) Although the conversion of Plg into the two-chain plasmin by tPA was accelerated in the presence of ST1 cells, the resulting plasmin molecules were almost exclusively in the extracellular environment. In similar assays with Staphylococcus aureus and Salmonella enterica, which have cell-bound Plg receptors, the conversion of Plg to plasmin is seen on the bacterial surface only (Kuusela \& Saksela, 1990; Lähteenmäki et al., 1995). (iii) In a 5 h incubation of ST1 cell suspension with Plg and tPA, over $90 \%$ of the enzymic activity generated was associated with the cell-free material. (iv) The extracellular material released from ST1 cells bound Plg and plasmin and also enhanced tPA- and uPA-catalysed Plg activation. (v) Plasmin formed by tPA was only weakly protected from $\alpha_{2} \mathrm{AP}$, which inhibits soluble plasmin with unoccupied kringle domains. However, the presence of enolase and GAPDH as well as Plg/plasmin binding were detected both on the surface of washed ST1 cells and in the extracellular proteome. Our hypothesis is that enolase and GAPDH interact with Plg in the cell wall, as well as after their release from the bacterial surface, and also in the extracellular phase. Enolase and GAPDH are enriched over time in the extracellular environment and are able to quickly react with Plg and its activators.

Enolase and GAPDH were major peptides in the extracellular proteome; they were also detected by IEM in cytoplasm and in the cell wall of L. crispatus ST1. These enzymes have been detected on the cell surface of various organisms, where they also function as Plg receptors and cellular adhesins (Pancholi \& Chhatwal, 2003). The predicted sequence of ST1 GAPDH exhibits high sequence identity, $80-90 \%$, to the orthologues in lactobacilli. On the other hand, the enolases are more diverse in Lactobacillus; the published sequences show $47-93 \%$ sequence identity and L. johnsonii contains three copies of the eno gene (Pridmore et al., 2004). The closest homologue to the ST1 enolase is in L. acidophilus (Altermann et al., 2005); the predicted sequences are $93 \%$ identical, which is in accordance with the close phylogenetic association of $L$. crispatus and L. acidophilus as species (Fujisawa et al., 1992; Johnson et al., 1980). Only one copy of eno is present in the genomic sequence of L. acidophilus (Altermann et al., 2005), making the gene essential for survival, and our ongoing genetic analyses have failed to produce evidence for more than one eno gene in L. crispatus ST1 (V. Hurmalainen, unpublished data). The mechanisms of secretion of enolase and GAPDH to the bacterial surface or exterior remain unknown. The presence of an auxiliary secA2 gene has been detected in Listeria, where it is involved in the secretion of various peptides, including enolase (Lenz et al., 2003). Two $\sec$ genes are also present in L. johnsonii; thus secA2 could affect secretion of one or more of the enolases of this bacterium (Pridmore et al., 2004). However, only a single $\sec A$ gene is present in the genome of $L$. acidophilus (Altermann et al., 2005) as well as in other Lactobacillus genomes available in the databases. Few reports have described a transient release of enolase and GAPDH proteins from the bacterial surface. Release and reassociation of enolase was reported in the cell surface of Strep. pneumoniae D39 (Bergmann et al., 2001), whereas in Strep. pyogenes D471 enolase remains surface-bound (Pancholi \& Fischetti, 1998), but GAPDH was released from the cell surface during iron starvation (Eichenbaum et al., 1996). Change of $\mathrm{pH}$ affects the release of enolase from the surface of Streptococcus gordonii (Nelson et al., 2001). These findings suggest that cell-wall association of enolase and GAPDH is reversible, and our hypothesis is that their efficient release from the ST1 surface results from loose interactions with other cell-wall structures rather than, for example, from more active secretion through the cytoplasmic membrane. We have also detected extracellular enolase and GAPDH in the culture medium of L. crispatus (V. Hurmalainen \& J. Antikainen, unpublished), and recent studies have demonstrated biologically active proteins in conditioned culture medium of L. rhamnosus (Peña \& Versalovic, 2003; Tao et al., 2006); this indicates that the presence of extracellular proteins in Lactobacillus is not a response to the PBS environment.

The number of Plg-binding proteins in the extracellular proteome of L. crispatus remains unresolved. We identified the presence of enolase and GAPDH in the ST1 extracellular proteome and showed that their $\mathrm{His}_{6}$-fusion forms from $E$. coli expressed Plg cofactor activity. $\mathrm{His}_{6}-\mathrm{GAPDH}$ of $L$. crispatus ST1 was more efficient than $\mathrm{His}_{6}$-enolase in Plg binding, and our ongoing research (V. Hurmalainen, unpublished) has shown that GAPDH isolated from ST1 supernatant also expresses Plg cofactor activity. Many of the $\mathrm{Plg} /$ plasmin-binding proteins, including enolases and GAPDH, from prokaryotes and eukaryotes harbour Cterminal lysines that are recognized by the kringle domains 
of Plg (Derbise et al., 2004; Winram \& Lottenberg, 1998). On the other hand, Bergmann et al. (2003) recently described an internal nine-residue Plg-binding motif in the enolase of Strep. pneumoniae. The sequence ${ }^{248} \mathrm{FYDKERKVY}$ is located on the surface of the octameric pneumococcal enolase, whereas the C-terminal lysines are located in the inter-dimer groove and apparently not accessible to $\mathrm{Plg}$ binding (Ehinger et al., 2004). The predicted ST1 enolase as well as the GAPDH sequence lack C-terminal lysines, and the ST1 enolase resembles pneumococcal enolase in having the sequence FYNKDDHKY starting at position 248. We are currently analysing which regions in ST1 enolase and GAPDH proteins are involved in Plg cofactor activity.

Our results show that extracellular enolase and GAPDH as well as the Plg activation cofactor function are common in species of Lactobacillus. We detected extracellular GAPDH in eight of the nine strains analysed in this study. Extracellular enolase was detected in six of the strains but not in L. paracasei, L. rhamnosus or Lactococcus lactis, which are phylogenetically distant from $L$. crispatus. Failure to detect extracellular enolase in the organisms may thus be due to lack of serological cross-reactivity, as the enolase sequences in lactic acid bacteria are variable. Species of Lactobacillus are members of the human microbiota and regarded as health promoting; however, isolates of $L$. acidophilus, L. rhamnosus and $L$. paracasei-species studied here - as well as some other species of Lactobacillus, are associated with the rare but dangerous opportunistic disease infective endocarditis (IE; Salvana \& Frank, 2006). The primary event in IE is bacterial adherence to damaged heart valves where the extracellular matrix is exposed. Isolates of Lactobacillus frequently adhere to extracellular matrices (Aleljung et al., 1991; McGrady et al., 1995), which contain components of the Plg system (Farina et al., 1996) and offer an environment where local Plg activation by lactobacilli could be functional and enhance tissue damage. On the other hand, a possible probiotic function could be interference with the exploitation of $\mathrm{Plg}$ by gastrointestinal pathogens that express Plg receptors or activators, such as Helicobacter pylori (Jönsson et al., 2004) or Salmonella (Lähteenmäki et al., 2005). The resolution of these questions is a challenging topic, and the lactobacilli-Plg interaction here described offers an interesting model to compare the $\mathrm{Plg} / \mathrm{plasmin}$ system in bacterial commensalism and pathogenicity.

\section{ACKNOWLEDGEMENTS}

This study has been supported by the Academy of Finland (the Microbes and Man Programme, grant numbers 105824, 211300, 80666 and 201967), the Alfred Kordelin Foundation, The Foundation for Nutritional Research, as well as the University of Helsinki.

\section{REFERENCES}

Aleljung, P., Paulsson, M., Emödy, L., Andersson, M., Naidu, A. S. \& Wadström, T. (1991). Collagen binding by lactobacilli. Curr Microbiol 62, 2244-2251.
Altermann, E., Russel, W. M., Azcarate-Peril, M. A., Barrangou, R. Buck, B. L., McAuliffe, O., Souther, N., Dobson, A., Duong, T. \& other authors (2005). Complete genome sequence of the probiotic lactic acid bacterium Lactobacillus acidophilus NCFM. Proc Natl Acad Sci U S A 102, 3906-3912.

Alvarez, R. A., Blaylock, M. W. \& Baseman, J. B. (2003). Surface localized glyceraldehyde-3-phosphate dehydrogenase of Mycoplasma genitalium binds mucin. Mol Microbiol 48, 1417-1425.

Antikainen, J., Anton, L., Sillanpää, J. \& Korhonen, T. K. (2002). Domains in the S-layer protein CbsA of Lactobacillus crispatus involved in adherence to collagens, laminin and lipoteichoic acids and in self-assembly. Mol Microbiol 46, 381-394.

Bastian, E. D. \& Brown, R. J. (1996). Plasmin in milk and dairy products: an update. Int Dairy J 6, 435-457.

Bergmann, S., Rohde, M., Chhatwal, G. S. \& Hammerschmidt, S. (2001). $\alpha$-Enolase of Streptococcus pneumoniae is a plasmin(ogen)binding protein displayed on the bacterial cell surface. Mol Microbiol 40, 1273-1287.

Bergmann, S., Wild, D., Diekmann, O., Frank, R., Bracht, D., Chhatwal, G. S. \& Hammerschmidt, S. (2003). Identification of a novel plasmin(ogen)-binding motif in surface displayed $\alpha$-enolase of Streptococcus pneumoniae. Mol Microbiol 49, 411-423.

Bergonzelli, G. E., Granato, D., Pridmore, R. D., Marvin-Guy, L. F., Donnicola, D. \& Corthésy-Theulaz, I. E. (2006). GroEL of Lactobacillus johnsonii Lal (NCC 533) is cell surface associated: potential role in interactions with the host and gastric pathogen Helicobacter pylori. Infect Immun 74, 425-434.

Boekhorst, J., Wels, M., Kleerebezem, M. \& Siezen, R. J. (2006). The predicted secretome of Lactobacillus plantarum WCFS1 shed light on interactions with the environment. Microbiology 152, 3175-3183.

Bolotin, A., Wincker, P., Mauger, S., Jailloin, O., Malarme, K., Weissenbach, J., Ehrlich, S. D. \& Sorokin, A. (2001). The complete genome sequence of the lactic acid bacterium Lactococcus lactis ssp. lactis IL1403. Genome Res 11, 731-753.

Broeseker, T. A., Boyle, M. D. P. \& Lottenberg, R. (1988). Characterization of the interaction of human plasmin with its specific receptor on a group A streptococci. Microb Pathog 5, 19-27.

Castellino, F. J. \& Ploplis, V. A. (2005). Structure and function of the plasminogen/plasmin system. Thromb Haemost 93, 647-654.

Chhatwal, G. S. (2002). Anchorless adhesins and invasins of Grampositive bacteria: a new class of virulence factors. Trends Microbiol 10, 205-208.

Coleman, J. L. \& Benach, J. L. (1999). Use of the plasminogen activation system by microorganisms. J Lab Clin Med 134, 567-576.

Derbise, A., Song, Y. P., Parikh, S., Fischetti, V. A. \& Pancholi, V. (2004). Role of the C-terminal lysine residues of streptococcal surface enolases in Glu- and Lys-plasminogen-binding activities of group A streptococci. Infect Immun 72, 94-105.

Edelman, S. (2005). Mucosa-adherent lactobacilli: commensal and pathogenic characteristics. $\mathrm{PhD}$ thesis, University of Helsinki.

Edelman, S., Westerlund-Wikström, B., Leskelä, S., Kettunen, H., Rautonen, N., Apajalahti, J. \& Korhonen, T. K. (2002). In vitro adhesion specificity of indigenous lactobacilli within the avian intestinal tract. Appl Environ Microbiol 68, 5155-5159.

Ehinger, S., Schubert, W.-D., Bergmann, S., Hammerschmidt, S. \& Heinz, D. W. (2004). Plasmin(ogen)-binding $\alpha$-enolase from Streptococcus pneumoniae: crystal structure and evaluation of plasmin(ogen)-binding sites. J Mol Biol 343, 997-1005.

Eichenbaum, Z., Green, B. D. \& Scott, J. R. (1996). Iron starvation causes release from the group A streptococcus ribosylating protein called plasmin receptor or surface glyceraldehyde-3-phosphate dehydrogenase. Infect Immun 64, 1956-1960. 
Farina, A., Tiberto, R. A., Tacconelli, A., Cappabianca, L., Gulino, A. \& Mackay, A. R. (1996). Identification of plasminogen in matrigel and its activation by reconstitution of this basement membrane extract. BioTechniques 21, 904-909.

Fujisawa, T., Benno, Y., Yaeshima, T. \& Mitsuoka, T. (1992). Taxonomic study of the Lactobacillus acidophilus group, with recognition of Lactobacillus gallinarum sp. nov. and Lactobacillus johnsonii sp. nov. and synonymy of Lactobacillus acidophilus group A3 (Johnson et al. 1980) with the type strain of Lactobacillus amylovorus (Nakamura 1981). Int J Syst Bacteriol 42, 487-491.

Johnson, J. L., Phelps, C. F., Cummins, C. S., London, J. \& Gasser, F. (1980). Taxonomy of the Lactobacillus acidophilus group. Int J Syst Bacteriol 30, 53-68.

Jönsson, K., Guo, B. P., Monstein, H.-J., Mekalanos, J. J. \& Kronvall, G. (2004). Molecular cloning and characterization of two Helicobacter pylori genes coding for plasminogen-binding proteins. Proc Natl Acad Sci U S A 101, 1852-1857.

Kleerebezem, M., Boekhorst, J., van Kranenburg, R., Molenaar, D., Kuipers, O. P., Leer, R., Tarchini, R., Peters, S. A., Sandbrink, H. M. \& other authors (2003). Complete genome sequence of Lactobacillus plantarum WSFS1. Proc Natl Acad Sci U S A 100, 1990-1995.

Kukkonen, M., Saarela, S., Lähteenmäki, K., Hynönen, U., Westerlund-Wikström, B., Rhen, M. \& Korhonen, T. K. (1998). Identification of two laminin-binding fimbriae, the type-1 fimbria of Salmonella enterica serovar typhimurium and the G fimbria of Escherichia coli, as plasminogen receptors. Infect Immun 66, 4965-4970.

Kuusela, P. \& Saksela, O. (1990). Binding and activation of plasminogen at the surface of Staphylococcus aureus. Increase in affinity after conversion to the Lys form of the ligand. Eur J Biochem 193, 759-765.

Lähteenmäki, K., Virkola, R., Pouttu, R., Kuusela, P., Kukkonen, M. \& Korhonen, T. K. (1995). Bacterial plasminogen receptors: in-vitro evidence for a role in degradation of the mammalian extracellular matrix. Infect Immun 63, 3659-3664.

Lähteenmäki, K., Kuusela, P. \& Korhonen, T. K. (2001). Bacterial plasminogen activators and receptors. FEMS Microbiol Rev 25, 531-552.

Lähteenmäki, K., Edelman, S. \& Korhonen, T. K. (2005). Bacterial metastasis: the host plasminogen system in bacterial invasion. Trends Microbiol 13, 79-85.

Lenz, L. L., Mohammadi, S., Geissler, A. \& Portnoy, D. A. (2003). SecA2-dependent secretion of autolytic enzymes promotes Listeria monocytogenes pathogenesis. Proc Natl Acad Sci U S A 100, 12432-12437.

Longstaff, C. \& Thelwell, C. (2005). Understanding the enzymology of fibrinolysis and improving thrombolytic therapy. FEBS Lett 579, 3303-3309.

Mangel, W. F., Lin, B. \& Ramakrishnan, V. (1990). Characterization of an extremely large, ligand-induced conformational change in plasminogen. Science 248, 69-73.

McGrady, J. A., Butcher, W. G., Beighton, D. \& Switalski, L. M. (1995). Specific and charge interactions mediate collagen binding by oral lactobacilli. J Dent Res 74, 649-657.

Mercenier, A., Pavan, S. \& Pot, B. (2003). Probiotics as biotherapeutic agents: present knowledge and future prospects. Curr Pharmaceut Design 9, 175-191.

Miettinen, M., Vuopio-Varkila, J. \& Varkila, K. (1996). Production of human tumor necrosis factor alpha, interleukin-6, and interleukin10 is induced by lactic acid bacteria. Infect Immun 64, 5403-5405.
Mitsuoka, T. (1969). Vergleichende Unterschungen über die Laktobazillen aus den Faeces von Menschen, Schweinen, und Hühnern. Zentralbl Bakteriol [Orig] 210, 32-51.

Myöhänen, H. \& Vaheri, A. (2004). Regulation and interactions in the activation of cell-associated plasminogen. Cell Mol Life Sci 61, 2840-2858.

Nelson, D., Goldstein, J. M., Boatright, K., Harty, D. W. S., Cook, S. L., Hickman, P. J., Potempa, J., Travis, J. \& Mayo, J. A. (2001). pHregulated secretion of a glyceraldehyde-3-phosphate dehydrogenase from Streptococcus gordonii FSS2: purification, characterization and cloning of the gene encoding this enzyme. J Dent Res 80, 371-377. Pancholi, V. \& Chhatwal, G. S. (2003). Housekeeping enzymes as virulence factors for pathogens. Int J Med Microbiol 293, 391-401.

Pancholi, V. \& Fischetti, V. A. (1992). A major surface protein on Group A streptococci is a glyceraldehyde-3-phosphate-dehydrogenase with multiple binding activity. $J$ Exp Med 176, 415-426.

Pancholi, V. \& Fischetti, V. A. (1998). $\alpha$-Enolase, a novel strong plasmin(ogen) binding protein on the surface of pathogenic streptococci. J Biol Chem 273, 14503-14515.

Peña, J. A. \& Versalovic, J. (2003). Lactobacillus rhamnosus GG decreases TNF- $\alpha$ production in lipopolysaccharide-activated murine macrophages by a contact-independent mechanism. Cell Microbiol 5, 277-285.

Plow, E. F., Herren, T., Redlitz, A., Miles, L. A. \& Hoover-Plow, J. L. (1995). The cell biology of the plasminogen system. FASEB J 9, 939-945.

Pridmore, R. D., Berger, B., Desiere, F., Vilanova, D., Barretto, C., Pittet, A.-C., Zwahlen, M.-C., Rouvet, M., Altermann, E. \& other authors (2004). The genome sequence of the probiotic intestinal bacterium Lactobacillus johnsonii NCC 533. Proc Natl Acad Sci U S A 101, 2512-2517.

Salvana, E. M. T. \& Frank, M. (2006). Lactobacillus endocarditis: case report and review of cases reported since 1992. J Infect 53, e5-e10.

Sijbrandi, R., Blaauwen, T. D., Tame, J. R. H., Oudega, B., Luirink, J. \& Otto, B. R. (2005). Characterization of an iron-regulated alphaenolase of Bacteroides fragilis. Microbes Infect 7, 9-18.

Tao, Y., Drabik, K. A., Waypa, T. S., Musch, M. W., Alverdy, J. C., Schneewind, O., Chang, E. B. \& Petrof, E. O. (2006). Soluble factors from the probiotic Lactobacillus GG activate MAP kinases and induce cytoprotective heat shock proteins in intestinal epithelial cells. Am J Physiol Cell Physiol 290, C1018-C1030.

Ullberg, M., Kronvall, G., Karlsson, I. \& Wiman, B. (1990). Receptors for human plasminogen on Gram-negative bacteria. Infect Immun 58, 21-25.

Ullberg, M., Kuusela, P., Kristiansen, B. E. \& Kronvall, G. (1992). Binding of plasminogen to Neisseria meningitidis and Neisseria gonorrhoeae and formation of surface-associated plasmin. J Infect Dis 166, 1329-1334.

Wang, L., Hayes, K. D. \& Mauer, L. J. (2006). Fluorescent labeling study of plasminogen concentration and location in simulated bovine milk systems. J Dairy Sci $\mathbf{8 9}, 58-70$.

Winram, S. B. \& Lottenberg, R. (1998). Site-directed mutagenesis of streptococcal plasmin receptor protein (Plr) identifies the C-terminal Lys334 as essential for plasmin binding, but mutation of the plr gene does not reduce plasmin binding to group A streptococci. Microbiology 144, 2025-2035.

Zhang, L., Seiffert, D., Fowler, B. J., Jenkings, G. R., Thinnes, T. C., Loskutoff, D. J., Parmer, R. J. \& Miles, L. A. (2002). Plasminogen has a broad extrahepatic distribution. Thromb Haemost 87, 493-501.

Edited by: M. Kleerebezem 